\title{
The National Water-Quality Assessment (NAWOA) Program Planned Monitoring and Modeling Activities for Texas, 2013-23
}

The U.S. Geological Survey's (USGS) National Water-Quality Assessment (NAWQA) Program was established by Congress in 1992 to answer the following question: What is the status of the Nation's water quality and is it getting better or worse?

Since 1992, NAWQA has been a primary source of nationally consistent data and information on the quality of the Nation's streams and groundwater. Data and information obtained from objective and nationally consistent water-quality monitoring and modeling activities provide answers to where, when, and why the Nation's water quality is degraded and what can be done to improve and protect it for human and ecosystem needs. For NAWQA's third decade (2013-23), a new strategic Science Plan has been developed that describes a strategy for building upon and enhancing the USGS's ongoing assessment of the Nation's freshwater quality and aquatic ecosystems.

\section{Surface-Water Activities}

NAWQA will characterize the status and trends of surface-water quality and aquatic ecosystems by monitoring ambient water-quality and ecological conditions through a National Fixed Site Network (NFSN). The NFSN will be the primary source of data for timely tracking and systematic annual reporting of national ambient conditions. The NFSN consists of 61 large river sites and 39 wadeable stream sites, most of which have been monitored by the USGS for 20 years or more. NFSN data, as well as data collected by State and other agencies, including various agencies in Texas, support the development and refinement of USGS regional waterquality models such as ones that can be used to estimate nutrient loads in Texas' river systems delivered to the Gulf of Mexico by Texas' rivers and streams.

Five NFSN monitoring sites are planned for Texas, three large river sites (Brazos, Rio Grande, and Trinity Rivers), and two wadeable streams, one draining a small watershed that is minimally disturbed by development (Frio River) and one that drains the heavily urbanized Dallas metropolitan area (White Rock Creek) (fig. 1 and table 1). Each of these sites will be sampled between 6 and 24 times per year, every year for basic waterquality properties $(\mathrm{pH}$, conductance, dissolved oxygen, and temperature), major ions, nutrients, organic carbon, and suspended sediment, and at four of the five sites, a comprehensive suite of pesticides and their breakdown products (table 1). At the two wadeable stream sites, ecological sampling of algal, macroinvertebrate, and fish communities will be sampled annually. By providing long-term, nationally consistent data on a suite of pesticides and other analytes not typically analyzed for by other agencies, NAWQA stream and river monitoring complements the extensive surface-water-quality monitoring done by the Texas Clean Rivers Program and its partners.

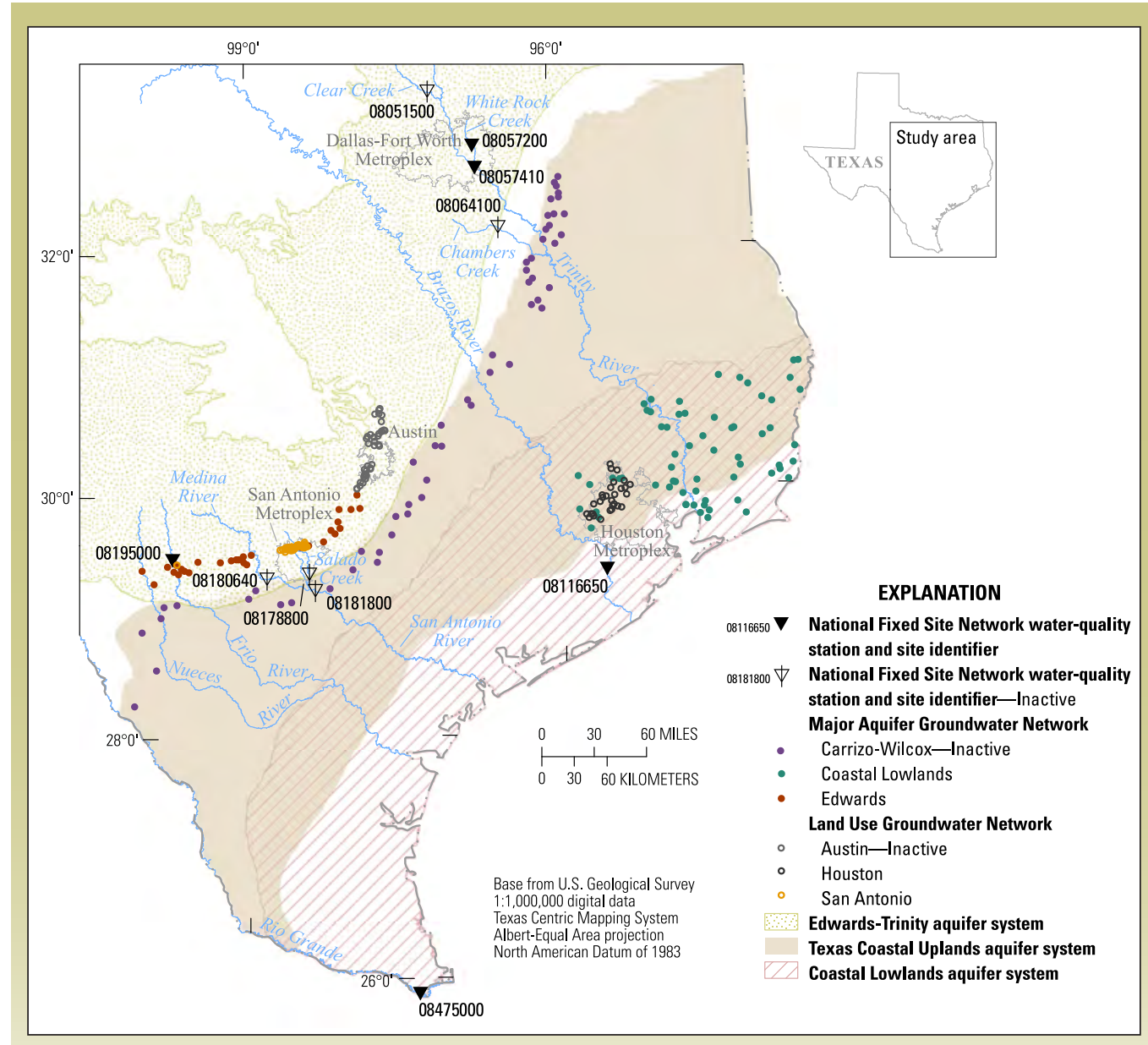

Figure 1. Streams and river locations in Texas that are part of the National Fixed Site Network that will be monitored throughout the year, every year, through 2023 as well as the locations of groundwater networks that are scheduled for sampling over the next decade. Also shown are inactive National Fixed Site Network sites and groundwater networks. 
Table 1. Texas streams and rivers selected for monitoring by National Water-Quality Assessment (NAWQA) Program, 2013-23.

[USGS, U.S.Geological Survey]

\begin{tabular}{|c|c|c|c|c|c|}
\hline $\begin{array}{c}\text { USGS } \\
\text { station number }\end{array}$ & USGS station name & Site type & $\begin{array}{l}\text { Ecological } \\
\text { sampling }\end{array}$ & $\begin{array}{l}\text { Number of } \\
\text { samples } \\
\text { per year }\end{array}$ & $\begin{array}{c}\text { Sampling history } \\
\text { (approximate total } \\
\text { samples/ time period) }\end{array}$ \\
\hline 08195000 & Frio River at Concan, Tex. & wadeable reference stream & yes & 6 & 150/1965-2004 \\
\hline 08057200 & $\begin{array}{l}\text { White Rock Creek at Greenville } \\
\text { Avenue, Dallas, Tex. }\end{array}$ & wadeable urban stream & yes & 24 & 200/ 1995-2011 \\
\hline 08057410 & Trinity River below Dallas, Tex. & large river & no & 18 & 750/ 1967-2012 \\
\hline 08475000 & Rio Grande near Brownsville, Tex. & large river & no & 12 & $350 / 1966-2012$ \\
\hline 08116650 & Brazos River near Rosharon, Tex. & large river & no & 14 & $350 / 1968-80,2008-12$ \\
\hline
\end{tabular}

\section{Groundwater Activities}

NAWQA is the only Federal program that assesses the status of the Nation's groundwater quality and reports on how these conditions are changing over time. Over the next decade, groundwater assessments are planned in 20 principal aquifers, which collectively account for more than 75 percent of the national groundwater used for drinking water. Water-quality data will be collected from the Coastal Lowlands aquifer of Texas (also referred to as the Gulf Coast aquifer system) and used with groundwater flow models to estimate the amount of groundwater available to the aquifer, the aquifer's vulnerability to contamination, and to gain an understanding of the way groundwater quality may respond to changes in climate, land use, and water use over time.

Groundwater monitoring planned for Texas over the next decade includes resampling of two domestic well major aquifer study networks in the Coastal Lowlands and Edwards aquifers, and resampling of two shallow monitoring well land-use study networks to assess trends in groundwater quality in aquifers beneath San Antonio and Houston (fig. 1 and table 2). NAWQA will also develop a new network that will sample 60 public supply wells to represent depths deeper than those tapped by domestic wells in the Coastal Lowlands, Texas Coastal Uplands, and Mississippi Embayment aquifer system across Texas and other Gulf Coast States. Wells will be sampled once for basic water-quality properties $(\mathrm{pH}$, conductance, dissolved oxygen, temperature), major ions, nutrients, organic carbon, trace elements, age-dating tracers, radionuclides, and an extensive suite of pesticides, volatile organic compounds, pharmaceuticals, and hormones. Analytical methods will be used to measure concentrations as low as economically and technically feasible. The resulting data will be used to detect subtle changes in groundwater quality, providing an early warning system of sorts before any appreciable changes occur. A subset of the wells will be sampled for microbial contaminants.

Table 2. National Water-Quality Assessment (NAWOA) Program groundwater studies planned in Texas, 2013-23.

\begin{tabular}{lccc}
$\begin{array}{c}\text { Groundwater } \\
\text { network }\end{array}$ & $\begin{array}{c}\text { Planned } \\
\text { fiscal } \\
\text { year for } \\
\text { sampling }\end{array}$ & $\begin{array}{c}\text { Number } \\
\text { of wells }\end{array}$ & $\begin{array}{c}\text { Sampling history } \\
\text { (approximate } \\
\text { total samples/ } \\
\text { time period) }\end{array}$ \\
\hline $\begin{array}{c}\text { Coastal Lowlands Major } \\
\text { Aquifer Study }\end{array}$ & 2014 & 64 & $145 / 1994-2011$ \\
$\begin{array}{l}\text { Coastal Lowlands Land } \\
\quad \text { Use Study }\end{array}$ & 2015 & 29 & $60 / 2003-11$ \\
$\begin{array}{l}\text { Edwards Major } \\
\text { Aquifer Study }\end{array}$ & 2016 & 30 & $200 / 1996-2012$ \\
Edwards Land Use Study & 2018 & 31 & $125 / 1998-2012$ \\
\hline
\end{tabular}

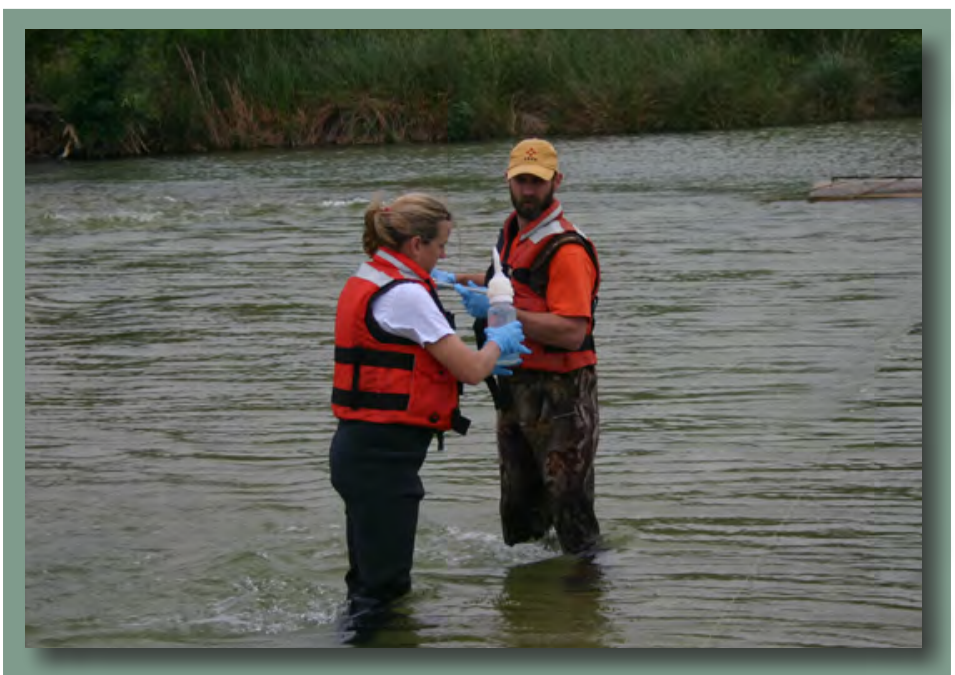

U.S. Geological Survey field crew sampling a National Water-Quality Assessment (NAWQA) Program surface-water site.

\section{Opportunities For Partnering With the U.S. Geological Survey}

Because of budget cuts, monitoring has been scaled back or eliminated from some long-term stations in Texas in the past few years within the NAWQA program (fig. 1). The NAWQA Program and the USGS Texas Water Science Center hope to restore monitoring at surface-water or groundwater stations where it has been scaled back or eliminated through cost-sharing efforts with USGS partners. The USGS welcomes opportunities to collaborate with other agencies to restore monitoring at inactive sites or to bolster planned monitoring or modeling activities. This could include expanding data collection at existing sites by adding continuous water-quality sensors or by augmenting laboratory analyses for additional chemical constituents to samples collected from NAWQA groundwater networks. Shared activities and funding increases the engagement of all levels of government - from local and State to national. Shared activities and funding maintain robust network operations, keep observations relevant to diverse uses, enhance cost-effectiveness, and aid network optimization and leveraging efforts.

\section{By Patricia Ging}

\footnotetext{
To discuss partnering opportunities, or for more information about NAWOA activities in Texas please contact:

Robert L. Joseph, Director (rljoseph@usgs.gov) or Patricia Ging, Hydrologist (pbging@usgs.gov)

1505 Ferguson Lane, Austin, TX 78754

Telephone (512) 927-3500 or visit http://tx.usgs.gov
} 